\title{
EDINBURGH JOURNAL
}

\section{OF BOTANY}

AN INTERNATIONAL JOURNAL OF PLANT SYSTEMATICS AND BIODIVERSITY

\author{
Editor-in-Chief \\ PROFESSOR JOHN RAVEN \\ Senior Editor \\ DR BRIAN COPPINS \\ Production Editor \\ KIM HOWELL \\ Book Review Editor \\ DR TOBY PENNINGTON
}

Volume 561999

No. 1 pages 1-160 (Published 26 February 1999)

No. $2161-320$ (Published 1 July 1999)

No. $321-478$ (Published 20 October 1999) 
Published by the Press Syndicate of the University of Cambridge The Edinburgh Building, Cambridge CB2 2RU, United Kingdom 40 West 20th Street, New York, NY 10011-4211, USA 10 Stamford Road, Oakleigh, Melbourne 3166, Australia

(C) Trustees of the Royal Botanic Garden Edinburgh, 1999 
VOLUME 56. NO. 3 (1999)

\section{CONTENTS}

lanhedgea (Brussicaceae). a new generic name replacing the illegitimate Microsisymbrium. I. A. AL-SHEHBAZ \& S. L. O'KANE JR

A revision of Geoffroea (Leguminoscw Papilionoideae). H. IRELAND \&

R. T. PENNINGTON

Two new species of Potentilla L. (Rosaceae) from SW Turkey. H. DUMAN \& R. R. MILL

Two new species of Campanula L. (Campanulaeeae) from SW Turkey. H. DUMAN

Nonea pallens (Boraginaceae). a new addition to the flora of Turkey. F. SKLVI

\& M. BIGA/ZI

Old World Gesneriaceae: VI. Six miscellaneous notes. B. L. BURTT

Notes relating to the flora of Bhutan: XXXIX. Gramineae II. H. J. NOLTIE

Meiotic studies of some Aegilops (Poaceae) species and populations in Iran. M. SHEIDAI. A. M. SAEED \& B. ZEHZAD

Pteridophyte flora of Lesvos (East Aegean Islands. Greece). I. BAZOS \& A. YANMTSAROS

Montane forest in the Dumoga Bone National Park. North Sulawesi. W. MILLIKEN \& J. PROCTOR

\section{Short communication}

The transfer of Harxeya alba to Alectra (Scroplndariaceae). B. L. BURTT 459

$\begin{array}{ll}\text { Book reviews } & 461\end{array}$

$\begin{array}{ll}\text { Referees } & 469\end{array}$

$\begin{array}{ll}\text { Index to Volume } 56 & 471\end{array}$

Volume contents 